\title{
Analysis Performance of Islamic Bank in Indonesia: Before and After the Spin Off
}

\author{
Rieke Pernamasari
}

\begin{abstract}
This research is a proof and analytic and experimental concept. This study aims to analyze the performance of Islamic Commercial Banks (BUS) before the spin off compared to the performance after the spin off. An example of this research is a BUS that has done a pure spin off or spin off conversion. Based on the selected sample, obtained 5 BUS that will be taken as research samples, namely BRI Syariah, BJB Syariah, BNI Syariah, Bukopin Syariah, and BTPN Syariah. The performance variable used is to measure using the CAR, NPF, NPM, ROA and BOPO ratios. The analytical method used is the paired sample t-test. The results showed that for 5 years before and after the spin-off, there were those that showed the significance of Islamic banking before and after the spin-off on BNI Syariah's performance. While the other 4 Islamic banks have significant differences and are not significantly different before and after the spin off.
\end{abstract}

Index Terms - spin off, sharia banking performance, sharia commercial bank.

\section{INTRODUCTION}

In its development, Islamic banks are not only in demand by Muslims but also by non-Muslims, so that several conventional banks both nationally and internationally have established Islamic Commercial Banks (BUS) originating from the establishment of new BUS, be it conversion from banks, spin offs and spin off conversions, [1]. The development of Islamic banks in Indonesia is also not only dominated by domestic banks whose majority shares are owned by the government or private companies in Indonesia, but also from foreign banks in Indonesia, such as Maybank which majority shares are owned by the State of Malaysia.

In order to accelerate significant growth, the Sharia Banking Law No.21 of 2008 emerged, one of which was to accelerate the growth of the Islamic banking industry in Indonesia. One of the important points of concern is article 68 paragraph 1 regarding the regulation of sharia spin-off business units. Where the criteria in the case of a Conventional Commercial Bank have a sharia business unit (UUS) whose asset value has reached at least $50 \%$ (fifty percent) of the total value of the parent bank's assets or 15 (fifteen) years since the entry into force of this Law, the Conventional Commercial Bank concerned is required to carry out Separation of UUS becomes a Sharia Commercial Bank. If this is not done, the bank will get sanctions in accordance with the applicable regulations in PBI No.11/ 10 / PBI / 2009 concerning Sharia Business Units. So that

Published on August 13, 2020

Rieke Pernamasari, University of Mercu Buana Jakarta, Indonesia.

(corresponding e-mail: rieke.pernamasari@mercubuana.ac.id) the separation of Sharia Business Units is carried out no later than 2023.

Seeing the laws above, the conventional commercial bank in question is obliged to separate UUS into a Islamic Commercial Bank (BUS). It is generally seen from this article that UUS spin-offs are mandatory after fulfilling one of the specified requirements, while also emphasizing that the existence of UUS has been temporary from the beginning [2]. Following are the number of Islamic banks in Indonesia and their formation:

TABLE 1. BANKS OF SHARIA IN INDONESIA

\begin{tabular}{|l|l|l|}
\hline No & Bank of Sharia & Information \\
\hline 1 & PT. Bank Aceh Syariah & Konversi \\
\hline 2 & PT. BPD Nusa Tenggara Barat Syariah & Konversi \\
\hline 3 & PT. Bank Muamalat Indonesia & Pendirian Baru \\
\hline 4 & PT. Bank Victoria Syariah & Konversi \\
\hline 5 & PT. Bank BRISyariah & Konversi dan spin off \\
\hline 6 & PT. Bank Jabar Banten Syariah & Spin off \\
\hline 7 & PT. Bank BNI Syariah & Spin off \\
\hline 8 & PT. Bank Syariah Mandiri & Konversi \\
\hline 9 & PT. Bank Mega Syariah & Konversi \\
\hline 10 & PT. Bank Panin Dubai Syariah & Konversi \\
\hline 11 & PT. Bank Syariah Bukopin & Konversi dan spin off \\
\hline 12 & PT. BCA Syariah & Konversi \\
\hline 13 & PT. Bank Tabungan Pensiunan Nasional & Konversi dan spin off \\
\hline 14 & PT. Maybank Syariah Indonesia & Konversi \\
\hline
\end{tabular}

Source: Financial Fervices Authority (OJK), 2019

Based on the data above, there are only 2 BUSs currently purely spinning off, namely PT BJB Syariah and PT BNI Syariah. The two BUSs were originally UUSs which separated from conventional parent banks and became fully independent BUSs as sharia banks without the involvement of their parent banks in conducting operations of Islamic banks. Then eight other BUS, namely Bank Aceh Syariah, Bank Syariah Mandiri, Bank Mega Syariah, Bank Panin Syariah, Bank Victoria Syariah, BPD Nusa Tenggara Barat Syariah, Maybank Syariah Indonesia, and BCA Syariah are the results of conversions that are generally the takeovers of small conventional banks by other banks and then the banks that were taken over were changed from conventional businesses to sharia-based businesses. While the other three BUSs resulting from the conversion were formed by converting a bank to be merged with an existing UUS, then the combined UUS was released (spin-off) into a BUS, namely BRI Syariah, BTPN Syariah, and Bukopin Syariah. In the history of Indonesian Islamic banking, there is only one BUS which is purely established / formed as a new 
bank, not originating from the conversion or spin-off results, namely Bank Muamalat.

There have been many studies regarding the spin off policy. Spin off company performance will tend to increase if operational activities relate to the involvement of the parent company and the CEO in the parent company in providing support to utilize the resources of the parent company. Second, spin-off companies have better performance in the early stages after leaving the parent company with technology that has been researched and developed by the parent company [3]-[5].

This result was strengthened by [6], according to him, the implications of spin offs on bank compliance in implementing sharia principles tended to increase. The spin off policy also has a good impact on increasing third party funds, besides the separation policy applied to the Islamic banking industry in Indonesia has a good effect on increasing profitability as measured by the Return on Asset (ROA) ratio. In addition, the spin-off model is more profitable than office channeling. The efficiency level of the spin-off model is higher than the office channeling model, the risk spin-off model is lower (more solvent) than the office channeling model, and there is no difference in the level of liquidity and asset quality between the spin-off model and the office channel model [7]-[9].

While from the effect of efficiency it turns out [10] found there is an influence between the separation policy towards the level of operational efficiency as measured by the ratio of Operational Costs to Operating Income (BOPO) at Islamic commercial banks, where the separation policy actually decreases the level of operational efficiency. This shows that after the separation policy actually results in the Islamic banking industry being less efficient than before the separation policy was carried out.

But the Spin-off policy also did not have a significant impact on assets and savings funds, even though total financing was found to increase significantly. Finally, the results show that the spin-off type has no impact on bank performance [11]. This result causes the operational costs of Islamic banks resulting from spinoffs to be higher than operating income, especially in the previous period of spinoffs, the value of operational efficiency (BOPO) is very high. Therefore, Islamic banks resulting from spin-offs will be more careful not to increase the operating costs of the financial portfolio. This result is also consistent with research [7] which shows that the dummy variable from spin-off, NPF and BOPO has a significant effect on profitability ratios (measured by ROA) of the Indonesian Sharia Banking Industry.

Research [1] on PT BNI syariah and PT BJB Syariah it was found that the performance of BNI Syariah before the spin off did not differ significantly after the spin off, but when it was spin off BNI Syariah was more daring to channel party funds through expansion financing compared before spin off. This condition is due after the spin off, BNI Syariah received an additional capital of Rp 1 trillion which is used for long-term investment such as organizational development, human resources, and information technology so that the benefits / benefits that have an impact on profitability cannot be felt in the short term. In addition, BNI Syariah has not been able to control the costs caused by spin off activities so that the level of profitability of the company after spinoff has decreased. However, after the spin off, BNI Syariah has more courage in channeling third party funds through financing expansion than before the spin off. Likewise with the results of research [12] has result that the method of separation whether it is pure separation or separation by means of acquisition, conversion and merger does not significantly influence the Return On Assets (ROA) of sharia commercial banks resulting from separation.

The more developing Islamic banks, of course, the more challenges faced. Especially in improving the performance of the bank itself, improving bank performance is very beneficial to increase the level of customer confidence in Islamic banks, [2]. Customers will certainly prefer Islamic banks with good performance, as seen in the income statement, balance sheet, financial ratio report, and others.

\section{LITERATURE AND HYPOTHESIS DEVELOPMENT}

\section{A. Agency Theory}

Agency theory states that there is an agency relationship as a contract between management as an agent and ownership as a company preliminary, a working relationship between the party that gives authority (preliminary), namely the shareholders and the recipient authority (agent) of the company in the form of cooperation, called the nexus of contract preliminary giving authority and authority to the agent to run the company in the interests of the owner and the principal [13]

\section{B. Spin Off Bank Sharia}

Separation or spin off according to Bank Indonesia Regulation No 11/10 / PBI / 2009 is Separation (spin-off) is the separation of businesses from one Conventional Commercial Bank (BUK) into two or more business entities in accordance with the provisions of the prevailing laws and regulations. In article 1 number 32 of Law number 21 of 2008 concerning Islamic banking provides the definition of spin off or separation as follows: Separation is the separation of business from one bank into two or more business entities, in accordance with statutory provisions.

Act Number 21 of 2008 article 68 explains as follows: In the case of a Conventional Commercial Bank having UUS whose asset value has reached at least $50 \%$ (fifty percent) of the total value of the parent bank's assets or 15 (fifteen) years since the entry into force of the Act - In this matter, the said Conventional Commercial Bank is required to carry out the Separation of UUS into a Sharia Commercial Bank.

Stamboel in [14] found three things most often encountered during the spin-off process, namely: First, the spin-off plan and brief information about the spin-off plan; Second, employee transfer; and Third, discrepancies between the regulations of the Minister of Justice and Bank Indonesia regulations. The business environment in Indonesia is more than ready to conduct spin-off transactions because State support is still adequate, this condition must be balanced with a set of laws and regulations that are conducive to the implementation of the process, and achieve legal certainty for all parties involved 
in the spin transaction -off.

The decision to spin off not only by internal factors within the company but also requires support from external conditions [15]. Companies with potential business units usually set targets to "let go" business units that are considered to have the ability and competence as standalone entities separate from the parent company. While from the external side, spin-off decisions must also be supported by regulations from related institutions as well as information about market opportunities that will be extracted after the business units are separated from the parent company.

Another reason that drives the spin off action is that the strategy is capable of producing better and more meaningful financial and accounting information. The spin off is considered capable of increasing incentives for management. Another positive impact that can result from the spin off process is the maximization of incentives for stakeholders, bearing in mind that after the spin off all business activities are actually carried out using resources owned by the parent company, [19]. With a more independent business process, targets can be set with more focus to generate incentives and bonuses with clearer standards and Islamic financial theory supports economic development directly into the world economy and physical transactions including prohibiting harmful activities and products, Islamic financial theory also promotes economic and social justice [20].

There are two types of sharia business unit separations that can be carried out in accordance with Bank Indonesia Regulations, first, establishing a new legal entity, where in this approach conventional commercial banks separate their UUS, then the UUS is made a Commercial Bank Sharia (BUS) alone. This type of separation is known as pure separation type. Second, using existing legal entities, where in this approach conventional commercial banks that have UUS acquire relatively small banks and then convert them into Islamic commercial banks, then conventional commercial banks that have Islamic business units separate and merge their UUS with banks that have just converted to BUS. This type of separation is usually called an impure separation type [16].

\section{Performance of Bank}

Performance is a result of achievements that have been set or determined by the company. Performance can also be interpreted into a series of financial statement activities in a certain period [17].

To measure banking performance, many are carried out in various ways. In this study, the measurement of sharia banking performance measured before and after the spin off is using the Capital Adequancy Ratio (CAR), nonperforming financing (NPF), Net Profit Margin (NPM), Return on Assets (ROA), and operating expenses against operating income (BOPO).
D. Hypothesis

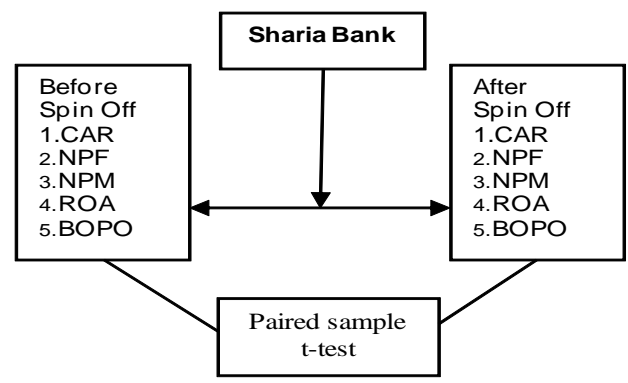

Fig. 1. FrameWork

Hypothesis:

H1: There are significant differences in performance Islamic banks in the CAR ratio before and after spin off

$\mathrm{H} 2$ : There are significant differences in performance Islamic banks on the NPF ratio before and after spin off

H3: There are significant differences in performance Islamic banks at NPM ratios before and after spin off

H4: There are significant differences in performance Islamic banks on the ROA ratio before and after spin off

H5: There are significant differences in performance Islamic banks at the BOPO ratio before and after spin off

\section{METHODOLOGY}

\section{A. Design Method}

This research is a type of research that uses content analysis with comparative causal bonds to analyze the performance of Islamic Banks that have done spin offs, both pure spin offs and spin off conversions.

\section{B. Population and Sample}

The population of this study is the Sharia Commercial Bank (BUS) registered with the Financial Services Authority (OJK). The research sample is BUS that has already done spin off, both pure spin off and spin off due to conversion.

TABLE 2: SAMPLE SELECTION

\begin{tabular}{|c|l|c|}
\hline No & Information & Quantity \\
\hline 1 & Number of Sharia Commercial Banks & 14 \\
\hline 2 & $\begin{array}{l}\text { Number of Sharia Commercial Banks } \\
\text { converting }\end{array}$ & -8 \\
\hline 3 & $\begin{array}{l}\text { Number of Sharia Commercial Banks } \\
\text { conducting new establishments }\end{array}$ & -1 \\
\hline $\begin{array}{l}\text { Number of Sharia Commercial Banks conducting } \\
\text { pure spin-offs and spin-off conversions }\end{array}$ & 5 \\
\hline
\end{tabular}

Source: Data processed, 2019

\section{Variable Operational}

The variables used to measure the performance of Islamic banking in this study are as follows:

1. Capital Adequancy Ratio (CAR).

2. Non Performing Financing (NPF).

3. Net Profit Margin (NPM).

4. Return on Assets (ROA). 


\section{Operating costs against operating income (BOPO).}

\section{Analysis Method}

Data analysis method used was paired sample t-test. Paired sample t-test is a procedure used to compare the average of two variables in one group. This means that this analysis is useful for testing two related samples or two paired samples. Paired t-test test in this study is used to prove the hypothesis that has been formulated, namely comparing CAR, NPF, NPM, ROA, and BOPO of Sharia Commercial Banks before and after the spin off are significantly different.

Paired Sample T Test results are determined by the significance value. This value then determines the decisions taken in the study.

1. Significance value (2-tailed) $<0.05$ indicates a significant difference between the initial variable and the final variable. This shows that there is a significant influence on the different treatments given to each variable.

2. Significance value (2-tailed) $>0.05$ indicates there is no significant difference between the initial variable and the final variable. This shows that there is no significant effect on the different treatment given to each variable.

\section{RESUlT AND DISCUSSION}

\section{A. Result}

Sharia Bank performance data before and after the spin off (per quarter) first conducted a normality test with Kolmogorov Smirnov to determine whether the data is normally distributed or not. The results of the normality test with Kolmogorov-Smirnov and data transformation can be seen in the table below:

TABLE 3: KOLMOGOROV SMIRNOV TEST RESULTS SHARIA BANK VARIABLE DATA BEFORE AND AFTER THE SPIN OFF

\begin{tabular}{|c|c|c|c|c|c|c|}
\hline \multirow[b]{3}{*}{ Rasio } & \multirow[b]{3}{*}{$\mathbf{N}$} & \multicolumn{5}{|c|}{ Kolmogorov - Smirnov } \\
\hline & & BRI & BJB & BNI & BUKOPIN & BTPN \\
\hline & & \multicolumn{5}{|c|}{ Sig (2-tailed) } \\
\hline CAR Before Spin Off & 22 & 0.200 & 0.055 & 0.600 & 0.200 & 0.200 \\
\hline CAR After Spin Off & 22 & 0.200 & 0.004 & 0.930 & 0.200 & 0.006 \\
\hline NPF Before Spin Off & 22 & 0.192 & 0.200 & 0.200 & 0.018 & 0.015 \\
\hline NPF After Spin Off & 22 & 0.200 & 0.154 & 0.200 & 0.200 & 0.018 \\
\hline NPM Before Spin Off & 22 & 0.000 & 0.200 & 0.360 & 0.000 & 0.200 \\
\hline NPM After Spin Off & 22 & 0.200 & 0.003 & 0.000 & 0.025 & 0.200 \\
\hline ROA Before Spin Off & 22 & 0.200 & 0.200 & 0.000 & 0.154 & 0.200 \\
\hline ROA After Spin Off & 22 & 0.710 & 0.200 & 0.000 & 0.200 & 0.144 \\
\hline BOPO Before Spin Off & 22 & 0.630 & 0.138 & 0.200 & 0.200 & 0.074 \\
\hline BOPO After Spin Off & 22 & 0.200 & 0.200 & 0.000 & 0.200 & 0.008 \\
\hline
\end{tabular}

Source: data processing, SPSS 22.

Based on Table 3 above, it can be concluded that from the results of the normality test with Kolmogorov-Smirnov, the Islamic bank variable data data still have data that are not normally distributed because the significance value is less than 0.05 . However, on average the sharia bank financial performance variable data before and after the spin off has normally distributed data.
TABLE 4: TEST RESULTS PAIRED SIMPLE T-TEST FOR BRI SYARIAH BEFORE AND AFTER THE SPIN OFF

\begin{tabular}{|l|r|r|r|}
\hline \multicolumn{1}{c}{ Rasio } & & \multicolumn{2}{c|}{ BRI } \\
\cline { 2 - 4 } & \multicolumn{1}{c|}{ Nean } & \multicolumn{1}{c|}{ Sig } \\
(\%) & (2-tail) \\
\hline CAR Before Spin Off & 22 & 16.31 & \\
CAR After Spin Off & 22 & 18.33 & 0.108 \\
\hline NPF Before Spin Off & 22 & 3.44 & \\
NPF After Spin Off & 22 & 2.62 & 0.028 \\
\hline NPM Before Spin Off & 22 & 18.26 & \\
NPM After Spin Off & 22 & 30.7 & 0.000 \\
\hline ROA Before Spin Off & 22 & 1.81 & \\
ROA After Spin Off & 22 & 2.13 & 0.356 \\
\hline BOPO Before Spin Off & 22 & 40.59 & \\
BOPO After Spin Off & 22 & 47.64 & 0.028 \\
\hline
\end{tabular}

Source: data processing, SPSS 22.

The test results in table 4 show that the CAR and ROA ratio at the BRI Syariah before and after the spin off is greater than 0.05 . So hypotheses 1 and 4 cannot be accepted, while hypotheses 2,3 and 5 are accepted.

TABLE 5: TEST RESULTS PAIRED SIMPLE T-TEST FOR BJB SYARIAH BEFORE

\begin{tabular}{|c|c|c|c|}
\hline \multirow[b]{2}{*}{ Rasio } & \multirow[b]{2}{*}{$\mathbf{N}$} & \multicolumn{2}{|c|}{ BJB } \\
\hline & & $\begin{array}{c}\text { Mean } \\
(\%)\end{array}$ & $\begin{array}{c}\text { Sig } \\
\text { (2-tail) }\end{array}$ \\
\hline CAR Before Spin Off & 22 & 16.74 & \\
\hline CAR After Spin Off & 22 & 22.79 & 0.000 \\
\hline NPF Before Spin Off & 22 & 0.73 & \\
\hline NPF After Spin Off & 22 & 2.61 & 0.000 \\
\hline NPM Before Spin Off & 22 & 18.79 & \\
\hline NPM After Spin Off & 22 & 16.98 & 0.107 \\
\hline ROA Before Spin Off & 22 & 1.47 & \\
\hline ROA After Spin Off & 22 & 1.23 & 0.343 \\
\hline BOPO Before Spin Off & 22 & 51.82 & \\
\hline BOPO After Spin Off & 22 & 433.35 & 0.006 \\
\hline
\end{tabular}

Source: data processing, SPSS 22.

From the test results in table 7 it can be seen that the ratio of NPM and ROA at BJB Syariah before and after the spin off is greater than 0.05 . So hypotheses 3 and 4 cannot be accepted, while hypotheses 1,2 , and 5 are accepted.

From the test results in table 6 it can be seen that the ratio of CAR, NPF, NPM, ROA and BOPO at BNI Syariah before and after the spin off is smaller than 0.05. So hypotheses 1,2,3,4 and 5 are accepted.

The test results in table 7 show that the ratio of NPM and ROA at BUKOPIN Syariah Bank before and after the spin off is greater than 0.05 . So hypotheses 3 and 4 cannot be accepted, while hypotheses 1,2 , and 5 are accepted. 
TABLE 6: TEST RESULTS PAIRED SIMPLE T-TEST FOR BNI SYARIAH BEFORE AND AFTER THE SPIN OFF

\begin{tabular}{|l|r|r|r|}
\hline \multicolumn{1}{|c|}{ Rasio } & & \multicolumn{2}{c|}{ BNI } \\
\cline { 2 - 4 } & \multicolumn{1}{c|}{ Mean } & Sig \\
(2) & & \multicolumn{1}{c|}{ (2-tail) } \\
\hline CAR Before Spin Off & 22 & 16.55 & \\
CAR After Spin Off & 22 & 18.72 & 0.002 \\
\hline NPF Before Spin Off & 22 & 9.44 & \\
NPF After Spin Off & 22 & 3.31 & 0.000 \\
\hline NPM Before Spin Off & 22 & 11.7 & \\
NPM After Spin Off & 22 & 29.81 & 0.000 \\
\hline ROA Before Spin Off & 22 & 0.6 & \\
ROA After Spin Off & 22 & 1.38 & 0.000 \\
\hline BOPO Before Spin Off & 22 & 30.2 & \\
BOPO After Spin Off & 22 & 56.89 & 0.000 \\
\hline
\end{tabular}

Source: data processing, SPSS 22.

TABLE 7: TEST RESULTS PAIRED SIMPLE T-TEST FOR BUKOPIN SYARIAH BEFORE AND AFTER THE SPIN OFF

\begin{tabular}{|l|r|r|r|}
\multicolumn{1}{c}{} & & \multicolumn{2}{c|}{ BUKOPIN } \\
\cline { 3 - 4 } \multicolumn{1}{c|}{ Rasio } & N & \multicolumn{1}{c|}{$\begin{array}{c}\text { Mean } \\
(\%)\end{array}$} & \multicolumn{1}{c|}{$\begin{array}{c}\text { Sig } \\
\text { (2-tail })\end{array}$} \\
\hline CAR Before Spin Off & 22 & 14.65 & \\
CAR After Spin Off & 22 & 16.85 & 0.003 \\
\hline NPF Before Spin Off & 22 & 4.78 & \\
NPF After Spin Off & 22 & 3.3 & 0.000 \\
\hline NPM Before Spin Off & 22 & 13.97 & \\
NPM After Spin Off & 22 & 14.92 & 0.353 \\
\hline ROA Before Spin Off & 22 & 0.85 & \\
ROA After Spin Off & 22 & 0.78 & 0.623 \\
\hline BOPO Before Spin Off & 22 & 37.83 & \\
BOPO After Spin Off & 22 & 45.13 & 0.000 \\
\hline
\end{tabular}

Source: data processing, SPSS 22.

TABLE 8: TEST RESULTS PAIRED SIMPLE T-TEST FOR BTPN SYARIAH BEFORE AND AFTER THE SPIN OFF

\begin{tabular}{|c|c|c|c|}
\hline \multirow[b]{2}{*}{ Rasio } & \multirow[b]{2}{*}{$\mathbf{N}$} & \multicolumn{2}{|c|}{ BTPN } \\
\hline & & $\begin{array}{c}\text { Mean } \\
(\%)\end{array}$ & $\begin{array}{c}\text { Sig } \\
\text { (2-tail) }\end{array}$ \\
\hline CAR Before Spin Off & 22 & 22 & \\
\hline CAR After Spin Off & 22 & 32.54 & 0.000 \\
\hline NPF Before Spin Off & 22 & 0.6 & \\
\hline NPF After Spin Off & 22 & 0.86 & 0.005 \\
\hline NPM Before Spin Off & 22 & 16.78 & \\
\hline NPM After Spin Off & 22 & 15.8 & 0.305 \\
\hline ROA Before Spin Off & 22 & 1.69 & \\
\hline ROA After Spin Off & 22 & 1.91 & 0.726 \\
\hline BOPO Before Spin Off & 22 & 36.55 & \\
\hline BOPO After Spin Off & 22 & 33.5 & 0.130 \\
\hline
\end{tabular}

Source: data processing, SPSS 22.

The test results in table 8 show that the ratio of NPM,
ROA and BOPO at BTPN Syariah before and after the spin off is greater than 0.05 . So hypotheses 3,4 and 5 cannot be accepted, while hypotheses 1 , and 2 are accepted.

\section{B. Discussion}

\section{Performance rasio CAR of Islamic Banks before and after the spin off}

Table test results show that only CAR in BRI Islamic banks there is no difference before and after the spin off, while in BJB, BNI, BUKOPIN and BTPN banks there are differences before and after the spin off. In the five Islamic banks, BNI Syariah banks and BJB Syariah are the pure spin-off results while the others are the spin-off results CAR conditions at BRI Syariah after the spin off still receive an injection of funds, but because the funds are used for working capital and investment in the context of developing a business that is just separated from the parent's conventional bank and becomes a fully BUS. In addition, Bank Indonesia provides provisions for banks to have a minimum CAR of $8 \%$, which causes banks to always maintain that their CAR is in accordance with the provisions, [1]. Research of [11] produces a spin-off policy does not affect the growth of spin-off bank assets, especially the spin-off policy on performance, as measured by assets, deposit funds, and growth of financing.

\section{Performance rasio NPF of Islamic Banks before and after the spin off}

Based on the results of table test, the performance of Islamic banking for the NPF ratio has a significant difference before and after the spin off. This shows that Islamic banks after the spin off will be more stringent in managing problem loans. Before the spin off of nonperforming loans has a high ratio, it can be said that Islamic banks are still under the umbrella of conventional parent banks, even BNI Syariah banks have a bad category because the NPF ratio is above $8 \%$ at the time before the spin off so it can be said that the problem loans are very high

The results of [1] said BNI Syariah after the spin off received an injection of funds of $\mathrm{Rp} 1$ trillion which was partly allocated to financing and improved from the aspect of supervision, thus impacting on better financing quality (NPF after spin off <NPF before spin off). This condition can cause the NPF ratio to have a significant difference before and after the spin off. However, the five Islamic banks maintain their NPF ratio after the spin off so that they are in the good category, ranging from $2 \%-5 \%$. Because a high NPF value can reduce customer confidence, [8].

\section{Performance rasio NPM of Islamic Banks before and after the spin off}

Based on the results of table 11, the performance of Islamic banking for the NPM ratio occurs significantly difference for BRI Syariah Bank and BNI Syariah before and after the spin off. The quality of BRI Syariah and BNI Syariah management after the spin off as measured by its ability to obtain a better margin of $12.44 \%$ and $18.11 \%$ compared to before the spin off. This means that BRI Syariah and BNI Syariah demonstrate the company's ability to generate net profits and focus more on managing its business, so that the management of BRI Syariah and BNI Syariah after the spin off can channel financing better which results in increased margin revenue. 
This result is in accordance with [1], but according to him the achievement of profit (margin) is still not optimal or not as expected because not all of the possible productive assets are in the form of financing (the real sector) but many are still placed in form of securities in which the level of profit sharing to be obtained is relatively smaller Sharia bannding compared to placement in the form of financing.

This NPM ratio is very important for operations managers because it reflects the company's strategy in controlling operating expenses. However, the other 3 banks BJB Syariah, Bukopin syariah and BTPN Syariah have no difference in the value of the NPM ratio before and after the spin off.

\section{Performance rasio ROA of Islamic banks before and after the spin off}

Based on the results of table tests, the performance of Islamic banking to ROA ratios occurs significant differences only at BNI Syariah. These results indicate the level of BNI Syariah profit after spin off from asset management is better by $0.78 \%$ compared to before sharia. While the other 4 Islamic banks did not occur before and after the spin off, even the average value of the BJB syariah bank and Bukopin Syariah a spin off value was smaller than before the spin off. This result shows that the four Islamic banks after the spin off were more focused, independent, flexible, responsive, and aggressive in managing their business, including in channeling their financing so that it had an impact on increasing margin revenue.

This result is in accordance with Al Arif (2016) in [18] with the criteria of sharia business unit asset values for conventional parent banks that have some weaknesses, namely, asset growth occurs either in sharia business units or conventional parent banks, so it will be difficult for sharia business units to reach an asset value of $50 \%$ from its parent bank. The sharia business unit must obtain greater asset growth than conventional parent banks, but if the sharia business unit pursues too much growth, it will cause longterm adverse effects.

\section{Performance rasio BOPO of Islamic banks before and after the spin off}

Based on the results of table tes, the performance of sharia banking for the BOPO ratio showed significant differences in BRI Syariah Bank, BJB Syariah, BNI Syariah and Bukopin Syariah before and after the spin off. While there is no significant difference in the Sharia BTPN. These results indicate that the three Islamic banks are more efficient in conducting operational activities after the spin off, because the average value of the BOPO ratio 5 years after the spin off shows a number $<95 \%$, which is in the good category.

The smaller this ratio means the more efficient operational costs incurred by banks. A small BOPO shows that bank operational costs are smaller than operating income. This shows that bank management is very efficient in carrying out its operational activities. If operational activities are carried out efficiently, the income generated by banks will rise, [7].

But in BJB Syariah the average value of BOPO after spin off reached $433 \%$, this result could be due to Sharia BJB not yet able to carry out its operational activities efficiently after spin off. This is because in the initial period of separation there will definitely be additional operational costs that have been borne by the parent bank, currently they must be borne by the Islamic bank itself, such as billing fees, legal fees, allowance for uncollectible allowance, administrative and general costs, and other costs, [10], [12]. Based on Bank Indonesia Circular No. 6/23 / DPNP 2004 that the criteria for a good BOPO ratio is $<95 \%$.

\section{CONCLUSION AND SUGGESTION}

\section{A. Conclusion}

In accordance with Sharia Banking Law No.21 of 2008, the separation policy is an obligation that must be carried out by conventional commercial banks that have opened sharia business units. Considering that the awareness of the community towards sharia banks continues to increase and some customers still doubt the purity of sharia principles in sharia business units operating under the auspices of conventional commercial banks, the conventional and sharia systems must operate respectively. So with the spin off, Islamic commercial banks can focus on running their sharia business more independently.

Statistical test results show that there are significant differences in the performance of Islamic banks before and after the spin off. However, some ratios have no difference, even though the average ratio after spin off is in the good category.

\section{B. Suggestion}

The data used in the study used 5 Indonesian sharia banks that had spun off either purely or converted to observation years 5 years before and after the spin off. It is therefore recommended for future research to use longer observational years data. This is intended so that the analysis is obtained more sharply and accurately in providing an overview of the effects of the spin-off policy on the performance of Islamic banking.

\section{REFERENCES}

[1] Chotib, A., \& Utami, W. (2016). Studi Kinerja Pt Bni Syariah Sesudah Pemisahan (Spin Off) Dari Pt Bank Bni (Persero) Tbk. Akuntabilitas, 7(2), 94-108. https://doi.org/10.15408/akt.v7i2.2661

[2] Pambuko, Z. B. (2019). Kebijakan Spin-Off dan Efisiensi Perbankan Syariah di Indonesia. Ihtifaz, 2(1), 21-38. https://doi.org/DOI: https://doi.org/10.12928/ijiefb.v2i1.822

[3] Chu, P. Y., Teng, M. J., Lee, C. T., \& Chiu, H. (2010). Spin-off strategies and performance: A case study of Taiwans Acer group. Asian Business and Management, 9(1), 101-125. https://doi.org/10.1057/abm.2009.24

[4] Cusatis, P. J., Miles, J. A., \& Woolridge, J. R. (1993). Restructuring through spinoffs. The stock market evidence. Journal of Financial Economics, 33(3), 293-311. https://doi.org/10.1016/0304405X(93)90009-Z

[5] Stempin, N. (2016). The Impact of Financial Statements For SEC Spin Off Entities On The Market's Ability To Anticipate Future Earnings (Georgia: Georgia State University). Retrieved from https://scholarworks.gsu.edu/bus_admin_diss

[6] Umam, K. (2010). Peningkatan Ketaatan Syariah Melalui Pemisahan (Spin-off) Unit Usaha Syariah Bank Umum Konvensional. Mimbar Hukum, 22(3), 607-624. https://doi.org/10.22146/jmh.16239

[7] Hamid, A. (2015). The Impact of Spin-Off Policy To The Profitability On Indonesian Islamic Banking Industry. Al-Iqtishad: Jurnal Ilmu Ekonomi Syariah, 7(1), 117-126. https://doi.org/10.15408/aiq.v7i1.1363

[8] Al Arif, M. N. R. (2014). Spin-off and its impact on the third party funds of Indonesian Islamic banking industry. Economic Journal of Emerging Markets, 6(1), 50-55. 
[9] Zulfikar, Sasongko, N. (2016). THE MODEL OF POLICY THE BANKING SERVICES TO ENHANCE COMPETITIVENESS ISLAMIC BANKING IN INDONESIAN. South East Asia Journal of Contemporary Business, Economics and Law, 11(1),1-8

[10] Al Arif, M. (2015). Keterkaitan Kebijakan Pemisahan Terhadap Tingkat Efisiensi Pada Industri Perbankan Syariah Di Indonesia. Jurnal Keuangan Dan Perbankan, 19(2), 295-304.

[11] Al Arif, M. N. R. ., Nachrowi, N. D., Nasution, M. E., \& Mahmud, T. M. Z. . (2017). The Islamic banking spin-off: Lessons from Indonesian Islamic banking experiences. Journal of King Abdulaziz University, Islamic Economics, 30(2), 117-133. https://doi.org/10.4197/Islec.30-2.11

[12] Al Arif, M. N. R., \& Dewanti, E. P. (2017). Metode Spin-Off Dan Tingkat Profitabilitas: Studi Pada Bank Umum Syariah Hasil Spin$\begin{array}{lll}\text { Off. } & \text { Iqtishadia, } & 10(1),\end{array}$ https://doi.org/10.21043/iqtishadia.v10i1.2316

[13] Jensen, M. C., \& Meckling, W. H. (1976). THEORY OF THE FIRM: MANAGERIAL BEHAVIOR, AGENCY COSTS AND OWNERSHIP STRUCTURE. Journal of Financial Economics, 3(4), 305-360. https://doi.org/10.1002/mde.1218

[14] Wulandari, L., Siregar, H., \& Tanjung, H. (2018). Spin Off Feasibility Study of Sharia Financing Unit: Study in Adira Finance. Al-Iqtishad: Jurnal Ilmu Ekonomi Syariah, 10(2), 299-312. https://doi.org/10.15408/aiq.v10i2.5781

[15] Rifin,Amzul. Saptono, I. T. D. (2015). Pemilihan Metode Spin Off Unit Bisnis Syariah Dengan Pendekatan Analisa Faktor ( Studi Kasus PT . BNI Syariah dan PT . Bank Syariah BRI ) Methods Selection of Sharia Business Unit Spin Off with Factor Analysis Approach ( case study PT . BNI Syariah dan PT. Jurnal AlMuzara'ah, 3(2), 123-135.

[16] Ratna. (2018). RENTABILITAS BANK UMUM SYARIAH SESUDAH SPIN-OFF BERDASARKAN TIPE PEMISAHANNYA DI INDONESIA. Amwaluna, 2(1), 83-100. https://doi.org/10.1017/CBO9781107415324.004

[17] Kasmir. (2018). Bank dan Lembaga Keuangan lainnya edisi Revisi 2014. Retrieved December 6, 2019, from RajaGrafindo Persada website: http://www.rajagrafindo.co.id/produk/bank-dan-lembagakeuangan-lainnya/

[18] Haribowo, I. (2016). The Indonesian Islamic Bank's Spin-off: A Study in Regional Development Banks. Al-Iqtishad: Journal of Islamic Economics, $\quad 9(1), \quad$ 53-68. https://doi.org/10.15408/aiq.v9i1.4308

[19] Rongiyati, S. (2015). Pengembangan Perbankan Syariah Melalui Pelaksanaan Kewajiban Pemisahan Unit Usaha Syariah. Negara Hukum, 6(1), 65-78.

[20] Tabash, M. I., \& Dhankar, R. S. (2014). The Relevance of Islamic Finance Principles in Economic Growth. International Journal of Emerging Research in Management and Technology, 3(2), 49-54.

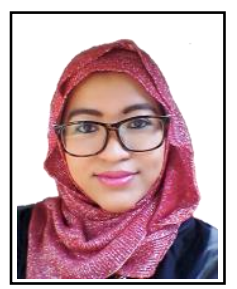

Rieke Pernamasari is a lecturer in the faculty of economics and business accounting study program from Mercu Buana University, Jakarta Indonesia. concentration of interest is financial accounting. She has been a lecturer since 2015. She tooks a master's degree in accounting at Mercu Buana University (2014) and a bachelor's degree in development studies at the University of Lampung, Indonesia (2007) 